\title{
ASSESSMENT OF SELECTED PHYSICAL CHARACTERISTICS OF THE ENGLISH RYEGRASS (LOLIUM PERENNE L.) WASTE BIOMASS BRIQUETTES
}

Artur Kraszkiewicz ${ }^{\mathrm{a}^{*}}$, Ignacy Niedziółka ${ }^{\mathrm{b}}$, Stanisław Parafiniuk ${ }^{\mathrm{c}}$, Maciej Sprawka $^{\mathrm{d}}$, Małgorzata Dula ${ }^{\mathrm{e}}$

a Department of Machinery Exploitation and Management of Production Processes, University of Life Sciences in Lublin, Poland, e-mail:artur.kraszkiewicz@up.lublin.pl ORCID 0000-0002-8031-0046

b Department of Agricultural, Forest and Transport Machinery, University of Life Sciences in Lublin, Poland, e-mail:ignacy.niedziolka@up.lublin.pl ORCID 0000-0002-9709-3375

c Department of Machinery Exploitation and Management of Production Processes, University of Life Sciences in Lublin, Poland, e-mail:stanislaw.parafiniuk@up.lublin.pl ORCID 0000-0002-8566-6527

d Department of Agricultural, Forest and Transport Machinery, University of Life Sciences in Lublin, Po-land, e-mail:maciej.sprawka@up.lublin.pl ORCID 0000-0002-3462-460X

e The Foreign Languages Teaching Centre of the University of Life Sciences in Lublin, University of Life Sciences in Lublin, Poland, e-mail:malgorzata.dula@up.lublin.pl ORCID 0000-0001-9239-1157

*Corresponding author: e-mail: artur.kraszkiewicz@up.lublin.pl

\begin{tabular}{|c|c|}
\hline ARTICLE INFO & ABSTRACT \\
\hline $\begin{array}{l}\text { Article history: } \\
\text { Received: September } 2019 \\
\text { Received in the revised form: } \\
\text { November } 2019 \\
\text { Accepted: December } 2019\end{array}$ & \multirow{2}{*}{$\begin{array}{l}\text { The aim of the study was to assess the selected physical characteristics } \\
\text { of the briquettes of English ryegrass waste biomass and its mixtures } \\
\text { with waste components from the agri-food industry: pea husks and oat } \\
\text { middlings. The raw materials used for the tests are characterized by } \\
\text { high calorific value and low ash content. Among the tested raw materi- } \\
\text { als, the most favorable values were recorded for oat middlings in this } \\
\text { respect. The produced briquettes were characterized by high volumetric } \\
\text { density and very diverse mechanical durability. At the same time, the } \\
\text { results of the tests on the mechanical durability of briquettes indicated } \\
\text { that the use of components of ryegrass mixtures selected for testing } \\
\text { brought unsatisfactory results, as compared to other analyzed physical } \\
\text { and energy features. }\end{array}$} \\
\hline $\begin{array}{l}\text { Key words: } \\
\text { briquetting, } \\
\text { biofuels, } \\
\text { physical features, } \\
\text { ryegrass }\end{array}$ & \\
\hline
\end{tabular}

\section{Introduction}

The development of civilization and technological progress is inextricably linked to the growing demand for efficient energy sources. At the same time, the need to protect the natural environment has increased, executed, among others, through the introduction of the concept of sustainable development, especially in rural areas. These phenomena have intensified the 
research on renewable energy carriers and the strive to develop effective methods of obtaining them from renewable sources

Biomass is one of the oldest energy resources known to man. It is the third largest energy source in the world, after coal and oil, satisfying approx. 14\% of global energy demand. Plant biomass comprises agricultural production waste, forest and wood industry waste, as well as energy crops, i.e. annuals and perennials grown for energy purposes. However, plant biomass as a fuel is a troublesome source of energy. In comparison with fossil fuels, it is often characterized by high humidity, lower calorific value and bulk density, strong hydrophilic properties and low milling properties. To improve the suitability of biomass for energy purposes, it is necessary to increase its density by pressure compacting loose material in the briquetting or pelleting process (Hejft, 2001; Frączek, 2010; Mani et al., 2003).

Research is being conducted worldwide, to systematize and present general considerations and arguments in favor of the use of biomass as an alternative energy source. What is of the greatest importance for all solid biofuels is moisture content, calorific value, fuel form, chemical composition, particle size and bulk density (Baxter, 2005; Brožek, 2016). These features heavily impact the biomass processing (shredding, briquetting) to obtain a product of adequate quality and mechanical strength. Knowledge of the physical and chemical properties of biomass is also necessary to determine the conditions for its storage and transport (Chin and Siddiqui, 2000; Mani et al., 2006; Matúš et al., 2015; Adapa et al., 2009; Ivanova et al., 2014; Wu et al., 2011).

One of the important processes in the production of briquettes is the shredding of biomass. Appropriate granulometric composition affects the density of the agglomerate obtained and allows optimizing the process of feeding plant material to the thickening unit of the briquetting press. Material shredded into smaller fractions is characterized by improved efficiency and easier passage into the working units of briquetting press, and thus allows obtaining briquettes with higher density. The finer the fragmentation of raw materials, the greater the density and kinetic stability of the briquette, the higher the efficiency of the briquetting process, and the lower the energy consumption (Mani et al., 2006; Niedziółka and Zuchniarz, 2009; Sypuła et al., 2010).

An important factor affecting the briquetting process is temperature. With its increase, the density and kinetic stability of the briquettes increases, and the stress relaxation time in the agglomerated product, and the friction coefficient between the walls and the compacted material decrease. Energy consumption is also lower, while process efficiency is improved (Kronbergs, 2000; Kaliyan and Morey, 2009; Panwar et al., 2011; Temmerman et al., 2006). The proper course of the briquetting process is also determined by the parameters of the working units of agglomerating devices (the shape of the pressing chamber, the applied compaction pressures, the flow rate of compacted material and the compaction speed). These factors primarily depend on the efficiency and energy consumption of the process, as well as the kinetic stability of the agglomerate (Hebda and Złobecki, 2012; Wilaipon, 2007).

English ryegrass, or perennial ryegrass, is the most popular grass in Poland. It grows naturally and is resistant to mechanical damage, which makes it an excellent base for pastures and lawns. Also, the significant interest of farmers in the production of seed grasses, as well as the quality requirements for seeds result in the availability of waste, which can be used for energy purposes after cleaning (Bałuch-Małecka et al., 2017; Gaj et al., 2014; Żabiński and Jezierski, 2011). 
Assessment of selected...

Therefore, selected physical characteristics of the briquettes of English ryegrass waste biomass and its mixtures with waste components from the agri-food industry, pea husks and oat middlings, were analyzed.

\section{Material and Methods}

Plant raw materials used for the research were in the form of waste biomass consisting of small parts of stems and seeds of English ryegrass, left after the process of seed cleaning, as well as the waste of the process of husking peas and oat middlings. Prior to compaction, the following characteristics of the accepted raw materials were determined:

- The particle size distribution of the fragmented raw materials was determined in accordance with PN-EN ISO 17827-2: 2016-07, using a laboratory shaker LPzE-4e with a set of sieves with holes of $3.15 ; 2.8 ; 2.0 ; 1.4 ; 1.0 ; 0.5$ and $0.25 \mathrm{~mm}$. To perform sieve analysis of the raw material, $100 \mathrm{~g}( \pm 1 \mathrm{~g})$ samples were shaken for $5 \mathrm{~min}$ at a frequency of 150 $\mathrm{Hz}$ and an amplitude of $10 \mathrm{~mm}$. Finally, the fractions on individual screens were weighed.

- The bulk density of the raw materials was determined in accordance with PN-EN ISO 17828:2016-02. The tests consisted of pouring a sample of the loose raw material into a $50 \mathrm{dm}^{3}$ container and then weighing it on a laboratory scale.

- The shaken density of the raw materials was determined using a laboratory shaker, in which the container with the raw material was shaken for $5 \mathrm{~min}$, at an amplitude of $10 \mathrm{~mm}$ and a frequency of $150 \mathrm{~Hz}$. The container with the raw material was subsequently weighed, and the decrease in the level of the raw material in the container was measured. Shaken density was calculated taking into account the volume obtained.

- Moisture content in the working condition was determined with an accuracy of $0.1 \%$, using the drying and weighing method according to PN-EN ISO 18134-3:2015.

- Combustion heat in a dry state was determined using an isoperibolical calorimeter of the Parr 6400 type, in accordance with the PN-EN ISO standard

- Dry ash content was determined using a laboratory oven in accordance with PN-EN ISO 18122:2016.

Next, three samples were prepared from the collected research material, with the following mass shares: $100 \%$ ryegrass waste (R-100), $75 \%$ ryegrass waste and $25 \%$ pea husks (R75$\mathrm{G} 25$ ) and $75 \%$ ryegrass waste and $25 \%$ oat middlings (R75-O25). When preparing the mixtures, the research material was moisturized to obtain $18 \%$ average moisture content of the agglomerated raw materials. The thus prepared research material was subjected to a compaction process in a hydraulic piston briquetting machine, the specification of which is presented in Table 1.

During the briquetting process, 25, 30 and $35 \mathrm{MPa}$ working pressure values were adopted, set with a valve. The biomass was fed into the briquetting press's compaction chamber with a double piston stroke. During the research, the energy consumption of this process was assessed using a Lumel N14 type electric meter with current transformers. The results of electricity consumption measurements were made in a triplicate and converted into a unit of mass of the produced briquettes. 
A. Kraszkiewicz, I. Niedziółka, S. Parafiniuk, M. Sprawka, M. Dula

Table 1.

Technical and operational data of a hydraulic piston briquetting machine

\begin{tabular}{lcc}
\hline Specification & Units & Date \\
\hline Diameter of briquettes & $(\mathrm{mm})$ & 50 \\
Maximum length of briquettes & $(\mathrm{mm})$ & 60 \\
$\begin{array}{l}\text { Efficiency of the briquetting } \\
\text { machine }\end{array}$ & $\left(\mathrm{kg} \cdot \mathrm{h}^{-1}\right)$ & 50 \\
Power of the electric motor & $(\mathrm{KW})$ & 7.5 \\
Maximum working pressure & $(\mathrm{MPa})$ & 15.0 \\
Capacity of the oil tank & $(\mathrm{dm})$ & 110 \\
Dimensions of the briquetting & $(\mathrm{mm})$ & $1600 \times 1100 \times 1500$ \\
machine $($ LxBxH) & $(\mathrm{kg})$ & 680 \\
Mass of the briquetting machine & &
\end{tabular}

Measurements of the physical characteristics of the produced briquettes included:

- Length, diameter and mass, which were tested in triplicate on 10 randomly chosen briquettes from a $1000 \mathrm{~g}( \pm 10 \mathrm{~g})$ sample. The length of the briquettes was determined using a caliper with a measurement accuracy of $\pm 1 \mathrm{~mm}$, while their mass was measured using a laboratory scales with a measurement accuracy of $\pm 0.1 \mathrm{~g}$.

- The bulk density of the briquettes was determined on the basis of measurements of their physical features, including geometrical dimensions and mass.

- The mechanical durability test of the briquettes was carried out on a test stand, in accordance with the PN-EN ISO 17831-2: 2016-02 standard. The rotational speed of the drum was $21 \mathrm{rpm}^{-1}\left( \pm 0.1 \mathrm{rpm}^{-1}\right)$, the test time was $5 \mathrm{~min}$, and the sample weight was $2000 \mathrm{~g} \mathrm{( \pm}$ $100 \mathrm{~g})$. After the durability test, the tested briquette samples were sieved on a $31.5 \mathrm{~mm}$ sieve.

The obtained measurement results were subjected to statistical analysis using ANOVA variance analysis of systematic factors. Homogeneous groups of mean values of briquettes were determined using the Tukey HSD test. The program Statistica ver. 13.1 was used for statistical analysis, and the significance level of the tests was $\alpha=0.05$.

\section{Results and Discussion}

The average values of the results obtained from the three replicates, characterizing the raw materials in terms of particle size distribution and other physical and chemical features, were presented in Tables 2 and 3.

The particle size distributions depended on the type of raw material and its susceptibility to fractioning. Among the considered raw materials, the pea husk waste was characterized by the most even distribution. For these types of waste, the over $3.15 \mathrm{~mm}$ particle size distribution was dominant, amounting to $24.79 \%$, while for the ryegrass and oat middlings the values were much lower, amounting to 3.98 and $4.81 \%$, respectively. The maximum values for ryegrass $(52.07 \%)$ and oat middlings $(26.29 \%)$ were observed on a sieve with $1.4 \mathrm{~mm}$ holes (Table 2). 
Assessment of selected...

Table 2.

Particle size distribution of the raw materials and plant waste used for briquetting (\%)

\begin{tabular}{lcccccccc}
\hline $\begin{array}{l}\text { Type of the raw } \\
\text { material }\end{array}$ & 3.15 & 2.8 & 2.0 & 1.4 & 1.0 & 0.5 & 0.25 & 0.0 \\
\cline { 2 - 8 } & & & & 0.0 & \\
\hline English ryegrass & 3.98 & 8.50 & 16.03 & 52.07 & 6.11 & 9.33 & 3.10 & 0.88 \\
Pea husks & 24.79 & 3.54 & 9.41 & 14.12 & 11.86 & 18.41 & 9.40 & 8.48 \\
Oat middlings & 4.81 & 5.17 & 21.55 & 26.29 & 12.29 & 16.27 & 8.84 & 4.77 \\
\hline
\end{tabular}

Table 3.

Physical and technical properties of the raw materials during research

\begin{tabular}{lcccc}
\hline Parameter & Unit & $\begin{array}{c}\text { English } \\
\text { ryegrass }\end{array}$ & $\begin{array}{c}\text { Pea } \\
\text { husks }\end{array}$ & Oat middlings \\
\hline Total moisture & $(\%)$ & 6.91 & 7.91 & 10.78 \\
Bulk density & $\left(\mathrm{kg} \cdot \mathrm{m}^{-3}\right)$ & 100.4 & 242.8 & 298.1 \\
Shaken density & $\left(\mathrm{kg} \cdot \mathrm{m}^{-3}\right)$ & 114.5 & 299.3 & 374.5 \\
Combustion heat & $\left(\mathrm{MJ} \cdot \mathrm{kg}^{-1}\right)$ & 19.13 & 19.50 & 21.01 \\
Ash & $(\%)$ & 3.71 & 2.53 & 1.85 \\
\hline
\end{tabular}

The differences in characteristics between the raw materials used for the tests were also observed when determining their bulk density. The lowest bulk density was identified in the ryegrass waste $\left(100.4 \mathrm{~kg} \cdot \mathrm{m}^{-3}\right)$, and the highest in oat middlings $\left(298.1 \mathrm{~kg} \cdot \mathrm{m}^{-3}\right)$. On the other hand, the shaken density was characterized by similar variability. Its values were higher than the bulk density by 14.23 and $26 \%$, respectively (Table 3 ).

In terms of energy features, oat middlings were characterized by the highest combustion heat $\left(21.01 \mathrm{MJ} \cdot \mathrm{kg}^{-1}\right)$, while for other raw materials the values of this parameter slightly exceeded $19 \mathrm{MJ} \cdot \mathrm{kg}^{-1}$. What is important, in terms of the selection of components for improving the energy features of briquettes, oat middlings were also characterized by the lowest ash content, i.e. $1.85 \%$. The highest value of this parameter $(3.71 \%)$ was observed for ryegrass waste (Table 3 ).

In terms of the parameters assessed, these values ranked among the best types of biomass for energy purposes (Demirbas, 2004, Eisenbies et al., 2016, Obernberger et al., 2006).

The diameter of the produced briquettes differed slightly and was approximately $50 \mathrm{~mm}$ $( \pm 0.5 \mathrm{~mm})$. However, greater diversity was observed among the other analyzed physical features. The results of length and mass tests of the produced briquettes, for the selected types of raw materials, and their mixtures, along with the working pressure levels of the briquetting press were presented in Figures 1 and 2. 
A. Kraszkiewicz, I. Niedziółka, S. Parafiniuk, M. Sprawka, M. Dula

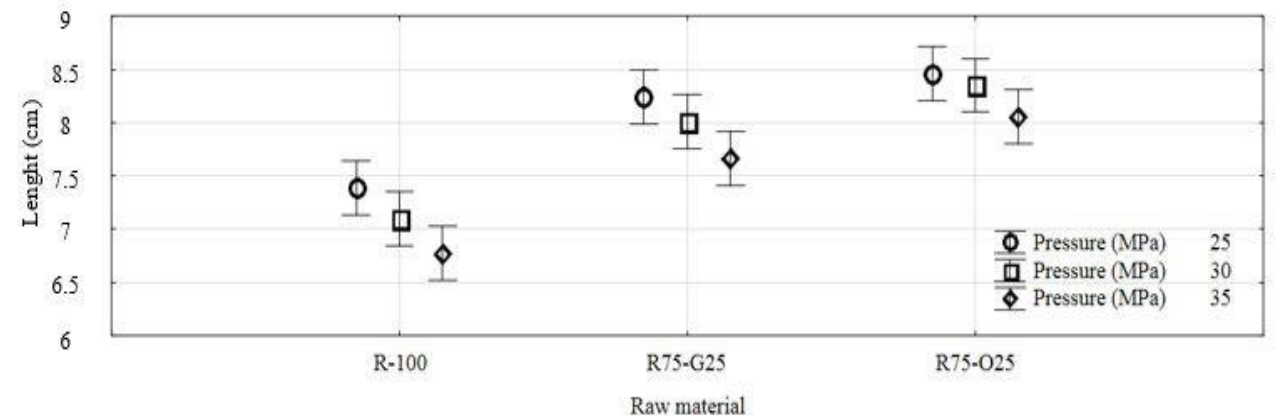

Figure 1. Average length of briquettes at a working pressure of the briquetting machine (bars represent 0.95 confidence intervals, $p=0.92206$ )

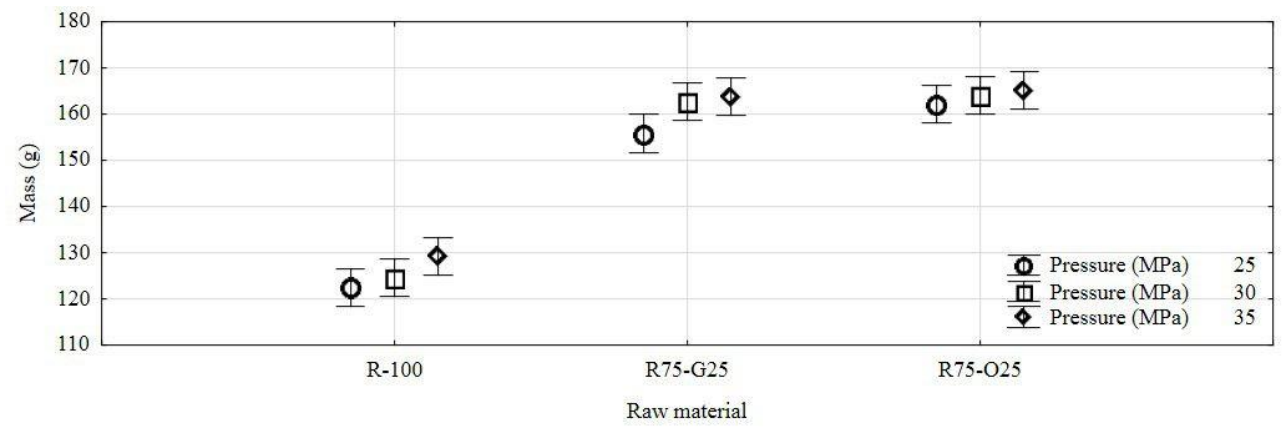

Figure 2. The average mass of briquettes at a working pressure of the briquetting machine (bars represent 0.95 confidence intervals, $p=0.55530$ )

The length of the briquettes was primarily influenced by the type and bulk density of the raw materials, and less by the briquetting pressure. The shortest briquettes were obtained from ryegrass waste (approx. $7 \mathrm{~cm}$ ), and the longest, from a mixture of ryegrass waste with oat middlings (approx. $8.5 \mathrm{~cm}$ ). In all cases, the increase in working pressure reduced the briquette length by almost $1 \mathrm{~cm}$. However, the statistical analysis performed for this parameter demonstrated no significant differences, $\mathrm{p}=0.92206$ (Fig. 1). The results of mass tests for the adopted variants of briquettes indicate that the lightest briquettes were obtained from ryegrass waste, with mass at approx. $125 \mathrm{~g}$. However, after adding the pea husk waste or oat middlings, the mass of the briquettes increased to approx. $165 \mathrm{~g}$. In this case, the increase in the working pressure of the briquetting machine increased their mass by nearly $10 \mathrm{~g}$, with the largest effect of pressure on this parameter observed for briquettes from ryegrass waste. Statistical analysis of the impact of pressure on this parameter demonstrated no significant differences, $\mathrm{p}=0.55530$ (Fig. 2).

The results of volumetric density tests of the produced briquettes, for the selected types of raw materials, and their mixtures, along with the working pressure levels of the briquetting 
Assessment of selected...

press were presented in Figures 1 and 3. The results of these tests for the adopted variants, as well as for the previously analyzed parameters, showed that the lowest volumetric density characterized the ryegrass waste briquettes (from 850 to $975 \mathrm{~kg} \cdot \mathrm{m}^{-3}$ ), while the briquetted mixtures were characterized by a slightly higher density (from 975 to $1100 \mathrm{~kg} \cdot \mathrm{m}^{-3}$ ). In all cases, the increase in the working pressure of the briquetting machine increased their density slightly above $100 \mathrm{~kg} \cdot \mathrm{m}^{-3}$. However, the statistical analysis performed for this parameter demonstrated no significant differences, $\mathrm{p}=0.13065$ (Fig. 3).

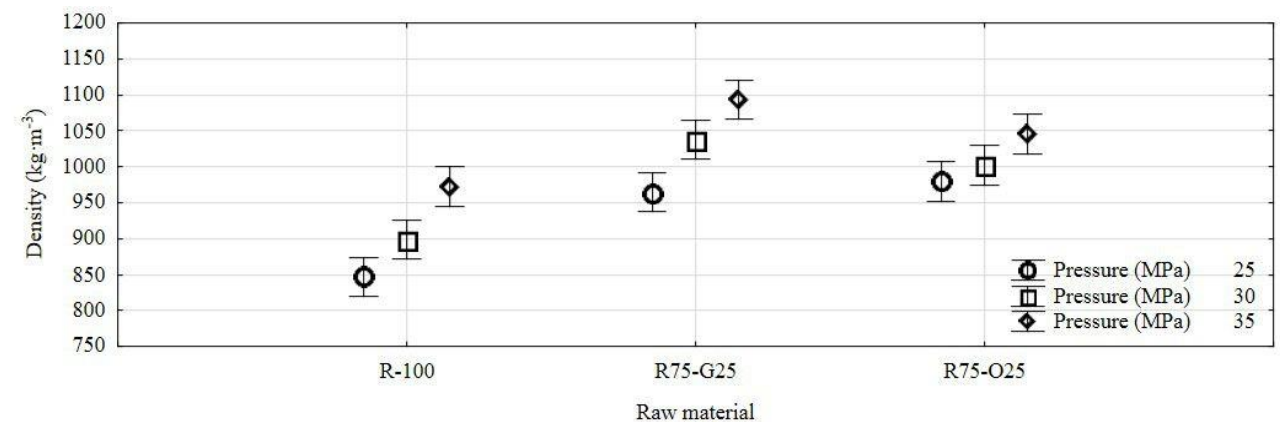

Figure 3. The average density of briquettes at a working pressure of the briquetting machine (bars represent 0.95 confidence intervals, $p=0,13065$ )

The results of mechanical durability tests of the produced briquettes, for the selected types of raw materials, and their mixtures, along with the working pressure levels of the briquetting press were presented in Figure 4.

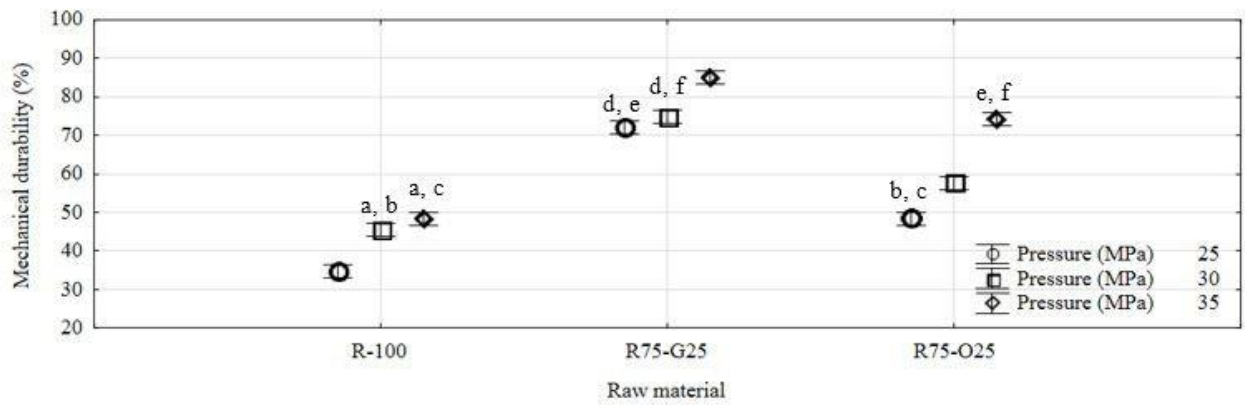

Figure 4. Average mechanical durability of the briquettes at a working pressure of the briquetting machine (bars represent 0.95 confidence intervals, $p=0,00000 ; a, b, c, d$, e, f statistically homogeneous groups are marked with the same letters) 
When it comes to mechanical durability tests, ryegrass waste without components continued to demonstrate the weakest characteristics. The durability of these briquettes ranged from 35 to $50 \%$. In contrast, briquettes made of mixtures were characterized by a slightly higher value of this parameter, with briquettes from ryegrass and pea husks being the most durable, at $80 \%$. It is very important that in all the variants the increase in pressure of the briquetting machine increased the mechanical durability of the briquettes by 10 to $25 \%$. The statistical analysis performed for this parameter demonstrated significant differences, $\mathrm{p}=0.00000$, and the Tukey's post-hoc test indicated six homogeneous groups (Fig. 4).

The research demonstrated that the geometrical parameters of English ryegrass waste biomass are improved in the process of its concentration in mixtures with pea husk waste and oat middlings. However, in terms of mechanical durability, the produced briquettes neither met the provisions of the applicable quality standards, nor were comparable due to the raw materials used and the results obtained, with the data presented in the literature (Demirbas, 2004, Eisenbies et al., 2016; Plíštil et al., 2005). However, the visible impact of physical characteristics on the mechanical durability of the briquettes was also demonstrated in studies by Ivanowa et al. (2018), as well as during own research on the concentration of other raw materials (Zawiślak et al., 2020).

\section{Conclusions}

Based on the conducted research and obtained results, the following conclusions were formulated:

1. The use of the tested plant raw materials for the production of briquettes is fully justified.

They are characterized by high calorific value and low ash content. Among the tested raw materials, the most favorable values of thermophysical features were found for oat middlings, with combustion heat at $21.01 \mathrm{MJ} \cdot \mathrm{kg}^{-1}$ and ash content at $1.85 \%$.

2. Apart from the type of the raw materials and their diversified bulk density, the length, mass, bulk density and mechanical durability of the briquettes were affected by the briquetting pressure. Based on the conducted tests, it was found that as the briquetting pressure increased, so did the mass, volumetric density and durability of the produced briquettes, while their length decreased.

3. The produced briquettes were characterized by high volumetric density, from 850 to $1100 \mathrm{~kg} \cdot \mathrm{m}^{-3}$ and very diverse mechanical durability, from just over $30 \%$ to over $80 \%$. At the same time, the results of the tests on the mechanical durability of briquettes indicated that the use of components of ryegrass mixtures selected for testing brought unsatisfactory results, as compared to other analyzed physical and energy features. 


\section{References}

Adapa, P., Tabil, L., Schoenau, G. (2009). Compaction characteristics of barley, canola, oat and wheat straw. Biosystems Engineering, 104(3), 335-344.

Bałuch-Małecka, A., Olszewska, M., Alberski, J. (2017). Plonowanie i wartość energetyczna wybranych gatunków traw wysokich. Łąkarstwo w Polsce (Grassland Science in Poland), 20, 7-24.

Baxter, L. (2005). Biomass-coal co-combustion: opportunity for affordable renewable energy. Fuel, 84, 1295-1302.

Brožek, M. (2016). The effect of moisture of the raw material on the properties briquettes for energy use. Acta Universitatis Agriculturae et Silviculturae Mendelianae Brunensis, 64, 1453-1458.

Chin, O.C., Siddiqui, K.M. (2000). Characteristics of some biomass briquettes prepared under modest die pressures. Biomass and Bioenergy, 18, 223-228.

Demirbas, A. (2004). Combustion characteristics of different biomass fuels. Progress in Energy and Combustion Science, 30, 219-230.

Eisenbies, M.H., Volk, T.A., Patel, A. (2016). Changes in feedstock quality in willow chip piles created in winter from a commercial scale harvest. Biomass and Bioenergy, 86, 180-190.

Frączek, J. (ed.). (2010). Przetwarzanie biomasy na cele energetyczne. PTIR Krakow. Kraków, Poland.

Gaj, R., Maciejewski, T., Rębarz, K. (2014). Effect of irrigation and nitrogen fertilization on phosphorus content in three grasses cultivated in field conditions. Journal of Research and Applications in Agricultural Engineering, 59(3), 41-44.

Hebda, T., Złobecki, A. (2012). Wpływ stopnia rozdrobnienia słomy na trwałość kinetyczną brykietów. Inżynieria rolnicza, 2(137), 57-64.

Hejft, R. (2001). Wpływ wilgotności materiału roślinnego i temperatury procesu na gęstość i wytrzymałość brykietów. Recyklace odpadu V, VSB-TU, Ostrava, 281-290.

Ivanova, T., Havrland, B., Novotny, R., Muntean, A., and Hutla, P. (2018). Influence of raw material properties on energy consumption during briquetting process. Contemporary Research Trends in Agricultural Engineering. BIO Web of Conferences, 10, 1-6.

Ivanova, T., Kolarikova, M., Havrland, B., Passian, L. (2014). Mechanical durability of briquettes made of energy crops and wood residues. Engineering for Rural Development, 131-136.

Kaliyan, N., Morey, R.V. (2009). Factors affecting strength and durability of densified biomass products. Biomass and Bioenergy, 33, 337-359.

Karpińska, M., Dul, Ł. (2014). Kierunki polityki energetycznej Polski oraz Unii Europejskiej w latach 2007-2030. Energetyka, 67, 3(717), 149-154.

Kronbergs, E. (2000). Mechanical strenght testing of stalk materials and compacting energy evaluation. Industrial Crops Production, 11(2-3), 211-216.

Mani, S., Tabil, L. G., Sokhansanj, S. (2006). Specific energy requirement for compacting corn stover Bioresource Technology, 97, 1420-1426.

Mani, S., Tabil, L.G., Sokhansanj, S. (2003). An overview of compaction of biomass grand. Powder Handling and Processing, 15(2), 160-168.

Matúš, M., Križan, P., Beniak, J., Šooš, L. (2015). Effects of initial moisture content on the production and quality properties of solid biofuel. Acta Polytechnica, 55(5), 335-341.

Niedziółka, I., Zuchniarz, A. (2009). Wpływ parametrów zagęszczania biomasy roślinnej na właściwości mechaniczne brykietów. Inżynieria Rolnicza, 8(117), 155-160.

Obernberger, I., Brunner, T., Bärnthaler, G. (2006). Chemical properties of solid biofuels - significance and impact. Biomass Bioenergy, 30, 973-982.

Obidziński, S., Hejft, R. (2013). Dobór parametrów techniczno-technologicznych procesu granulowania odpadów roślinnych. Inżynieria i Aparatura Chemiczna, 52(3), 210-212.

Panwar, V., Prasad, B., Wasewar, K. (2011). Biomass residue briquetting and characterization. Journal of Energy Engineering, 137/2, 108-114.

Plíštil, D., Brožek, M., Malaták, J., Roy, A., Hutla, P. (2005). Mechanical characteristics of standard fuel briquettes on biomass basis. Research in Agricultural Engineering, 51(2), 66-72. 
PN-EN ISO 17827-2:2016-07. Solid biofuels - Determination of particle size distribution - Part 2: Vibrating screen method using sieve apertures of $3,15 \mathrm{~mm}$ and below.

PN-EN ISO 17828:2016-02. Solid biofuels - Determination of bulk density.

PN-EN ISO 17831-2:2016-02. Solid biofuels - Determination of the mechanical strength of pellets and briquettes - Part 2: Briquettes.

PN-EN ISO 18122:2016. Solid biofuels - Determination of ash content.

PN-EN ISO 18125:2017. Solid biofuels - Determination of calorific value.

PN-EN ISO 18134-3:2015. Solid biofuels - Determination of moisture content - Oven dry method Part 3: Moisture in general analysis sample.

Sypuła, M., Lisowski, A., Chlebowski, J., Nowakowski, T., Strużyk, A. (2010). Bulk density of chopped material of energetic plants. Annals of University of Life Sciences - SGGW Agriculture (Agricultural and Forest Engineering), 56, 29-37.

Temmerman, M., Rabier, F., Daugbjerg-Jensen, P., Hartmann, H., Böhm, T. (2006). Comparative study of durability test methods for pellets and briquettes. Biomass and Bioenergy, 30, 964-972.

Wilaipon, P. (2007). Physical characteristics of maize cob briquette under moderate die pressure. American Journal of Applied Sciences, 4(12), 995-998.

Wu, M.R., Schott, D.L., Lodewijks G. (2011). Physical properties of solid biomass. Biomass and Bioenergy, 35, 2093-2105.

Zawiślak, K., Sobczak, P., Kraszkiewicz A., Niedziółka I., Parafiniuk S., Kuna-Broniowska, I., Tanaś W., Żukiewicz-Sobczak, W., Obidziński, S., (2020). The use of lignocellulosic waste in the production of pellets for energy purposes. Renewable Energy, 145, 997-1003.

Żabiński, A., Jezierski, T. (2011). The impact of repeated tractor passes on growth dynamics and yielding of perennial ryegrass Lolium perenne L. Agricultural Engineering, 5(130), 299-306.

\section{OCENA WYBRANYCH CECH FIZYCZNYCH BRYKIETÓW Z BIOMASY ODPADOWEJ RAJGRASU ANGIELSKIEGO (LOLIUM PERENNE L.)}

Streszczenie. Celem pracy była ocena wybranych cech fizycznych brykietów z biomasy odpadowej rajgrasu angielskiego po jego czyszczeniu oraz w mieszankach, wykorzystując do ich produkcji komponenty z przemysłu rolno-spożywczego w postaci odpadów po obłuskiwaniu grochu i śruty owsianej. Wykorzystane do badań surowce charakteryzują się wysoką wartością opałową i niską zawartością popiołu, a spośród badanych surowców w tym zakresie najkorzystniejsze wartości odnotowano dla śruty owsianej. Wytworzone brykiety charakteryzowały się dużą gęstością objętościową i bardzo zróżnicowaną trwałością mechaniczną. Przy czym wyniki badań trwałości mechanicznej brykietów najbardziej zweryfikowały, zasadne pod względem energetycznym, jak również analizowanych pozostałych cech fizycznych, wykorzystanie wybranych do badań komponentów w mieszankach z odpadami rajgrasu.

Słowa kluczowe: brykietowanie, biopaliwa, cechy fizyczne, rajgras 